\title{
EGFR is dispensable for c-Met-mediated proliferation and survival activities in mouse adult liver oval cells
}

Martínez-Palacián $A^{a}$, del Castillo $G^{a l}$, Herrera $B^{a}$, Fernández $M^{a}$, Roncero $C^{a}$, Fabregat $I^{b}$, Sánchez $A^{a_{\xi}}$.

${ }^{a}$ Dep. Bioquímica y Biología Molecular II, Facultad de Farmacia, Universidad Complutense, Madrid, Spain. apalacian@farm.ucm.es, gdelcastillo@iiib.uam.es, bm.herrera@farm.ucm.es, margafdz@farm.ucm.es, ceronce@farm.ucm.es.

${ }^{\mathrm{b}}$ Laboratori d'Oncologia Molecular and Departament de Ciències Fisiològiques II, Universitat de Barcelona, Institut d'Investigació Biomèdica de Bellvitge, L'Hospitalet de Llobregat, Barcelona, Spain. ifabregat@idibell.cat.

Corresponding author: Dr. A. Sánchez. Dep. Bioquímica y Biología Molecular II, Facultad de Farmacia, Universidad Complutense, Plaza Ramón y Cajal S/N, 28040-Madrid, Spain. Phone \#: 34-91-3941627. Fax \#: 34-91-3941779. munozas@farm.ucm.es

\begin{abstract}
Liver progenitor cells rise as potential critical players in hepatic regeneration but also carcinogenesis. It is therefore mandatory to define the signals controlling their activation and expansion. Recently, by using a novel in vitro model of oval cell lines expressing a mutant tyrosine kinase-inactive form of c-Met we demonstrated that autocrine c-Met signalling plays an essential role in promoting oval cell survival. Here, we investigated the significance of the epidermal growth factor receptor (EGFR) signalling in oval cell proliferation and survival, as well as a potential functional crosstalk between the c-Met and the EGFR pathways. We found an autocrine activation of the EGFR-triggered pathway in Met $\mathrm{fl}^{\mathrm{fl} / \mathrm{fl} x}$ and $\mathrm{Met}^{-{ }^{--}}$
\end{abstract}

\footnotetext{
'Present address: Instituto de Investigaciones Biomédicas "Alberto Sols", 28029Madrid, Spain.
} 
"oval cells as judged by constitutive expression of the EGFR ligands, transforming growth factor-alpha (TGF- $\alpha$ ) and heparin-binding EGF like growth factor (HB-EGF), and activation of EGFR. On the other hand, treatment with AG1478, a specific inhibitor of EGFR, effectively blocked endogenous and EGFinduced proliferation, while increased serum withdrawal and transforming growth factor-beta (TGF- $\beta$ )-induced apoptosis. These results suggest that constitutively activated EGFR might promote oval cell proliferation and survival. We found that hepatocyte growth factor (HGF) does not transactivate EGFR nor EGF transactivates c-Met. Furthermore, treatment with AG1478 or EGFR gene silencing did not interfere with HGF-mediated activation of target signals, such as protein kinase $B(A K T / P K B)$, and extracellular signal-regulated kinases 1/2 (ERK $1 / 2$ ), nor did it have any effect on HGF-induced proliferative and antiapoptotic activities in Met ${ }^{\text {fl/flix }}$ cells, showing that HGF does not require EGFR activation to mediate such responses. EGF induced proliferation and survival equally in $\mathrm{Met}^{\mathrm{fl|} / \mathrm{fl} \mathrm{x}}$ and $\mathrm{Met}^{-{ }^{-}}$oval cells, proving that EGFR signalling does not depend on cMet tyrosine kinase activity. Together, our results provide strong evidence that in normal, untransformed oval cells, c-Met and EGFR represent critical molecular players to control proliferation and survival that function independent of one another.

Keywords: c-Met, EGFR, signalling, oval cell, survival, proliferation

\section{Introduction}

\footnotetext{
" Abbreviations: 2-AAF/PH, 2-acetylaminofluorene/partial hepatectomy; AKT/PKB, AKT/protein kinase B; DMEM, Dulbecco's modified Eagle's medium; EGF, epidermal growth factor; EGFR, epidermal growth factor receptor; ERK 1/2, extracellular signal-regulated kinases 1/2; FBS, fetal bovine serum; HB-EGF, heparin-binding EGF-like growth factor; HCC, hepatocellular carcinoma; HGF, hepatocyte growth factor; MAPK, mitogen activated-protein kinase; PI3K, phosphatidylinositol-3 kinase; PLC- $\gamma$, phospholipase C-gamma; RLEC, rat liver epithelial cells; RTK, receptor tyrosine kinase; STAT3, signal transducer and
} 
The adult progenitor oval cells are among the most popular and best studied liver stem/progenitor cell populations. These cells constitute a heterogeneous population that emerge and expand in the liver parenchyma as a result of chronic liver injury, subsequently differentiate into hepatocytes and are responsible for the progenitor-dependent liver regeneration [1,2]. Besides their regenerative potential solid evidence support their involvement in liver cancer $[3,4]$. This dual role emphasizes the urge to learn more about these cells. Particularly important is to put forth efforts to dissect the signalling network regulating their development, fate and function. An increasing number of factors and signalling pathways, including growth factors, inflammatory cytokines, chemokines, and hormones, are being identified and/or postulated as major regulators of oval cell proliferation, differentiation and homeostasis, picturing a quite complex and unclear scenario. Among others, the well-known receptor tyrosine kinase (RTK) signaling systems, HGF/c-Met, and EGF/EGFR (also known as ErbB1), are certainly interesting targets for experimental studies. Both signalling pathways have a remarkably pleiotropic nature and share common intracellular signalling molecules and biological effects, playing fundamental roles during development and oncogenesis [ 5-8]. The HGF actions, namely proliferation, survival, motility, and morphogenesis, are driven by ligand bindingdependent autophosphorylation of c-Met on specific tyrosine residues in the tyrosine kinase and C-terminal domains, followed by either adapter-mediated or direct recruitment and activation of multiple signal transducers, including RasERK 1/2 mitogen activated protein kinases (MAPKs), phosphatidylinositol-3 kinase (PI3K)-AKT, phospholipase C- $\gamma$ (PLC- $\gamma$ ), p38, and STAT3 [9]. EGF, on the other hand, binds to and activate the EGFR, which is part of a complex signalling system that includes up to 15 different ligands, transforming growth factor alpha

activator of transcription-3, TGF- $\alpha$, transforming growth factor-alpha; TGF- $\beta$, transforming growth factor-beta. 
(TGF- $\alpha$ ) included, and four transmembrane receptors, ErbB1 (Her1/EGFR), ErbB-2 (Her2/neu), ErbB-3 (Her3), and ErbB-4 (Her4) [10,11]. Similarly to HGF pathway, ligand binding results in dimerization and autophosphorylation of the receptor in tyrosine residues of the cytoplasmic domain. Receptor activation leads to recruitment of adapter proteins, such as Grb2 and Shc, and subsequent activation of diverse downstream effectors, most of which are shared between the Met and ErbB1 pathways, mediating cell proliferation, migration, differentiation and evasion from apoptosis.

Evidence of a role for both HGF and TGF- $\alpha$ signalling systems in progenitor cellmediated regeneration is available in the literature. Indeed, both TGF- $\alpha$ and HGF, as well as their respective receptors, ErbB1 and c-Met, are transcriptionally up-regulated during the period of active proliferation and differentiation of progenitor cells in the rat liver subjected to the 2-acetylaminofluorene/partial hepatectomy (2-AAF/PH) protocol [12-14]. Furthermore, in vivo infusion with either EGF or HGF amplifies liver progenitor expansion following liver injury and decreases cell apoptosis [15]. Recently, using a novel in vitro model of oval cell lines harboring a genetically inactivated c-met tyrosine kinase, we have demonstrated that c-Met-supported signalling plays an essential role in promoting oval cell survival but is dispensable for proliferation [16]. We have also seen that EGF elicits mitogenic activity in mouse oval cells in vitro. However, the degree of functional redundancy, cooperation or dependence between these two signalling pathways in oval cells remains unknown. To this effect, it is well known that c-Met-signalling is modulated by direct communication with other receptors. In fact, a direct cross-talk between c-Met and ErbB1 has been proposed in a variety of cell systems, modulating c-Met-driven downstream signalling and cellular responses. For instance, mitogenic activity of HGF on rat primary hepatocytes has been reported to be dependent on TGF- $\alpha$ synthesis and ErbB1 
activation $[17,18]$. In addition, cross-talk between these two RTKs appears to have significant implications in oncogenesis, where aberrant activation of one RTK may lead to overexpression and activation of the other [19].

On this basis, we undertook the present study to evaluate the significance of the EGFR signalling pathway on oval cell proliferation and survival and to explore whether a direct crosstalk between EGFR and c-Met exists in these cells and its contribution, if any, to c-Met signalling. Using a combined genetic and chemical approach, we demonstrate for the first time that an EGFR-mediated autocrine signalling promotes oval cell proliferation and survival in vitro, being cMet tyrosine kinase dispensable for EGFR-triggered actions. Furthermore, chemical inhibition of EGFR kinase activation does not prevent HGF-induced DNA synthesis and protection against apoptosis in mouse oval cells. Together, our data provide direct evidence that, although both c-Met and EGFR-driven signals support oval cell growth and survival, their respective tyrosine kinase activities are not mutually dependent upon one another.

\section{Material and Methods}

\subsection{Reagents and antibodies}

Mouse recombinant HGF was purchased from R\&D Systems (Minneapolis, MN). EGF was from Serono Laboratories (Madrid, Spain). Human recombinant TGF- $\beta$ and AG1478 were from Calbiochem (La Jolla, CA). Dulbecco's modified Eagle's medium (DMEM), fetal bovine serum (FBS) and trypsin-EDTA were from Gibco-Invitrogen (Barcelona, Spain). Penicillin, streptomycin, HEPES, bovine serum albumin (fraction $\mathrm{V}$, fatty-acid free), propidium iodide, DNA oligos, and all buffer reagents were from Sigma-Aldrich (Tres Cantos, Madrid, Spain). RNeasy Kit was from Qiagen (Valencia, CA). 
SuperScript III RNase H Reverse Transcriptase was from Invitrogen. Oligo-dT was from Roche Diagnostics (Sant Cugat del Valles, Barcelona, Spain). [ $\left.{ }^{3} \mathrm{H}\right]$ thymidine $(25.0 \mathrm{Ci} / \mathrm{mmol})$, HRP-conjugated secondary antibody, and $\mathrm{ECL}$ reagent, were from GE Healthcare Europe (Barcelona, Spain). Caspase-3 substrate was obtained from PharMingen (San Diego, CA). The rabbit polyclonal antibodies: anti- EGFR (CS-2232), anti-phospho EGFR (CS-2236), anti-STAT3 (CS-9132), anti-phospho STAT3 (Ser 727) (CS-9134), anti-AKT (CS-9272), antiphospho-AKT (Ser 473) (CS-9271), anti-p44/p42 MAPK (Erk 1/2) (CS-9102), anti-phospho-p44/p42 MAPK (Erk 1/2) (Thr202/Tyr204) (CS-9101), were purchased from Cell Signaling (Beverly, MA). A rabbit polyclonal against c-Met (sc-162) was from Santa Cruz Biotechnology, Inc., (Paso Robles, CA). A mouse monoclonal antibody against phospho-tyrosine (recombinant clone 4G10) was from Upstate Biotechnology, Inc., (Lake Placid, NY) and mouse monoclonal anti$\beta$-actin (clone AC-15) antibody was from Sigma-Aldrich. Protein A-agarose beads were from Roche and anti-mouse lgG (whole molecule)-agarose was from Sigma.

\subsection{Cell Lines and Culture Conditions}

$\mathrm{Met}^{\mathrm{fl} / \mathrm{flf}}$ and $\mathrm{Met}^{-{ }^{-}}$oval cell lines were generated as described previously [16]. Cells were routinely maintained in DMEM supplemented with $10 \%$ FBS in a humidified incubator at $37^{\circ} \mathrm{C}$ and a $5 \% \mathrm{CO}_{2}$ atmosphere. Medium was replaced every three days, and cells were harvested at $80 \%$ to $90 \%$ confluence using trypsin-EDTA and replated at 1:10 dilution for maintenance. After an overnight attachment period, medium was replaced by serum-free DMEM. Cells were maintained in serum-free medium for $4-12 \mathrm{~h}$ prior to treatment with growth factors. HGF was added before the TGF- $\beta$ treatment for a minimum of 6 hours. AG1478 was added 30 min before addition of growth factors. 
2.3 Reverse Transcriptase-Polymerase Chain Reaction (RT-PCR) Analysis

Total cellular RNA was isolated using the RNeasy Kit (Qiagen, Valencia, CA). RNA yield and purity were analyzed using a spectrophotometer (UV-visible recording spectrophotometer Specord 205, AnalytikJena). Three $\mu \mathrm{g}$ total RNA was reverse-transcribed into complementary DNA using SuperScript III RNase H Reverse Transcriptase and oligo-dT as a primer. The PCR primers were as follows: $h b$-egf (forward GACCCATGCCTCAGGAAATA, reverse TGAGAAGTCCCACGATGACA), tgf- $\alpha$ (forward TGGTGCAGGAAGAGAAGC, reverse TGACAGCAGTGGATCAGC), $\beta$-actin (forward ATGCCATCCTGCGTCTGGACCTGG, reverse GCATTTGCGGTGCACGATGGAGGG).

Cycling parameters were: denaturation at $94^{\circ} \mathrm{C}$ for 1 minute, annealing temperatures of 57 to $65^{\circ} \mathrm{C}$ for 1 minute, and extension at $72^{\circ} \mathrm{C}$ for 1 minute (30 to 35 cycles of amplification). Amplified products were subjected to electrophoresis in 1.2 to $1.5 \%$ agarose gels and stained with ethidium bromide for visualization.

\subsection{DNA Synthesis Analysis}

Cells were plated at a density of 17,500 cells/sq $\mathrm{cm}$ in DMEM with $10 \%$ FBS. The following day, cells were incubated for 48 hours in serum-free medium with or without growth factors, epidermal growth factor $(20 \mathrm{ng} / \mathrm{ml})$ or HGF $(40 \mathrm{ng} / \mathrm{ml})$. Incorporation of ${ }^{3} \mathrm{H}$-thymidine during the last 40 hours of culture was measured in trichloroacetic acid precipitable material following a previously described protocol [20].

2.5. Measurement of Apoptotic Index 
The following day after cell seeding, the complete medium was replaced by serum-free DMEM with or without exogenous factors and/or inhibitor, AG1478 $(5 \mu \mathrm{M})$, TGF- $\beta(1 \mathrm{ng} / \mathrm{ml})$, EGF $(20 \mathrm{ng} / \mathrm{ml})$, HGF $(40 \mathrm{ng} / \mathrm{ml})$. Cells undergoing apoptosis were scored under inverted fluorescence microscope (Eclipse TE300, Nikon) at high magnification (x60) following standard morphological criteria, such as chromatin condensation, nuclear pyknosis, and nuclear fragmentation. A cluster of closely packed apoptotic bodies was scored as one. Cells were stained with propidium iodide as described [21] and apoptotic indices were calculated after counting a minimum of 1000 cells per treatment in a blinded manner.

\subsection{Measurement of Caspase-3-Like Enzymatic Activity}

A fluorometric assay in the presence of Ac-DEVD-AMC as fluorogenic Caspase-3 substrate was used following a previously described procedure [22]. Cleavage of the substrate was monitored in a Microplate Fluorescence Reader FL600 (Bio-Tek) (excitation, $380 \mathrm{~nm}$; emission, $440 \mathrm{~nm}$ ). A unit of caspase activity is the amount of enzyme that will lead to a one unit increase in the fluorescence intensity. Protein concentration was estimated and results are expressed as units of activity per microgram of protein.

\subsection{Immunoprecipitation and Immunoblotting}

For phospho-EGFR immunoprecipitation, cells were lysed in a buffer containing $50 \mathrm{mM}$ Tris, pH7.5; $150 \mathrm{mM}$ sodium chloride; 1\% NP-40; 5 mM EGTA; $5 \mathrm{mM}$ EDTA, supplemented with $1 \mathrm{mM}$ phenylmethylsulfonyl fluoride, $10 \mu \mathrm{g} / \mathrm{ml}$ aprotinin and leupeptin, and $1 \mathrm{mM}$ sodium orthovanadate. $500-1000 \mu \mathrm{g}$ of protein was incubated overnight at $4^{\circ} \mathrm{C}$ with antibody against phospho-tyrosine. The following day, complexes were precipitated for $1 \mathrm{~h}$ at $4^{\circ} \mathrm{C}$ with anti-mouse lgG whole molecule-agarose antibody. Pellets were washed three times with the lysis 
buffer and heated for $5 \mathrm{~min}$ at $95^{\circ} \mathrm{C}$ in Laemmli sample buffer for western blot analysis using an antibody against EGFR.

For Met immunoprecipitation, total cell extracts prepared with a lysis buffer containing $10 \mathrm{mM}$ Tris, pH 7.4; $150 \mathrm{mM}$ sodium chloride; 1\% NP-40; 1\% sodium deoxycholate; $0.1 \%$ SDS; 2 mM EDTA; plus protease and phosphatase inhibitors (as described above), were immunoprecipitated using a rabbit polyclonal anti-cMet antibody and protein A-agarose beads. The solubilized immunoprecipitates were processed as above and analyzed by Western blotting using an antiphosphotyrosine antibody.

For standard western blotting (without immunoprecipitation), total cell extracts were prepared in modified RIPA buffer: $30 \mathrm{mM}$ Tris pH 7.5; $150 \mathrm{mM}$ sodium chloride; $1 \%$ NP40; $0.5 \%$ sodium deoxycholate; $0.1 \%$ SDS; 5 mM EDTA supplemented with $1 \mathrm{mM}$ phenylmethylsulfonyl fluoride, $10 \mu \mathrm{g} / \mathrm{ml}$ aprotinin and leupeptin; $1 \mathrm{mM}$ sodium orthovanadate. 40 to $80 \mu \mathrm{g}$ of protein were separated in $10-12 \%$ acrylamide sodium dodecyl sulfate-polyacrylamide electrophoresis gels and blotted to Immobilon-P membranes (Millipore, Bedford, MA). Membranes were probed with the primary antibodies diluted 1:500 to 1:1000 in Tris-buffered saline containing $0.1 \%$ Tween 20 and $0.5 \%$ non-fat dried milk or $0.5 \%$ bovine serum albumin according to manufacturer's instructions. Detection was done using the enhanced chemiluminescence method and autoradiography.

\subsection{Statistical Analysis}

Statistical analysis was performed by Student's t-test analysis. The differences were assumed significant at $P<0.05$.

\section{Results}

3.1. Oval cells express EGFR ligands and show constitutive activation of EGFR 
Aiming to understand the relevance of EGFR signalling in adult liver progenitor oval cells and to explore a potential cross-talk between EGFR and Met in these cells, Met ${ }^{f \mid f f f l}$ and Met $^{-/-}$oval cells were first investigated for the expression of EGFR ligands transcripts using semiquantitative RT-PCR. For this, cells were cultured in complete medium (10\%FBS) or serum-free medium for 24 hours and total RNA was used for detecting $h b$-egf and tgf- $\alpha$ mRNAs. Transcripts encoding these two ligands were detected both in $\mathrm{Met}^{\mathrm{fl} / \mathrm{ffl}}$ and $\mathrm{Met}^{-{ }^{--}}$oval cells, in the presence or absence of serum, demonstrating a constitutive expression of the EGFR ligands $h b$-egf and tgf- $\alpha$ in mouse oval cells (Fig. 1A). Previous experiments had evidenced that Met $\mathrm{fl}^{\mathrm{fl} / \mathrm{fl} x}$ and $\mathrm{Met}^{-{ }^{-}}$oval cells express EGFR, since both cell lines respond to EGF with an increase in cell proliferation [16]. Based on the simultaneous expression of EGFR and EGFR ligands, we hypothesized that an autocrine EGFR-mediated signalling could be active in oval cells. To test this idea, we analyzed the phosphorylation state of EGFR in Met $\mathrm{f}^{\mathrm{fl} / \mathrm{fl} x}$ and $\mathrm{Met}^{-1-}$ oval cells in basal conditions (in the absence of serum and exogenous stimuli) and compared to that in EGF-stimulated cells. After immunoprecipitation of cell lysates with anti-phosphotyrosine antibody and subsequent immunoblot analysis with anti-EGFR antibody, a prominent $170 \mathrm{kDa}$ tyrosine-phosphorylated band corresponding to the EGFR was detected in oval cells treated for $10 \mathrm{~min}$ with EGF $(20 \mathrm{ng} / \mathrm{ml})$. Although less intense, a $170 \mathrm{kDa}$ band was also seen in

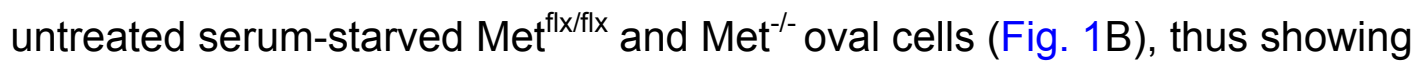
endogenous phosphorylation of EGFR in both oval cell lines. These results provide strong evidence for an autocrine EGFR signalling in mouse oval cells.

3.2. EGFR-mediated signalling promotes proliferation and survival in mouse oval cells

EGFR ligands are well-known inducers of proliferation and survival in 
hepatocytes [23,24]. In vivo evidences suggest similar roles for the EGFR ligands/EGFR axis in liver progenitor cells $[13,15]$. Therefore, to evaluate the functional relevance of the autocrine EGFR signalling in $\mathrm{Met}^{\mathrm{fl} / \mathrm{flx}}$ and $\mathrm{Met}^{-/-}$oval cells, we next examined the effect of inhibiting EGFR activity on oval cell proliferation and survival. Proliferation was assessed by measuring the rate of oval cells DNA synthesis by tritiated-thymidine incorporation into DNA. As shown in Fig. 2A, EGF is a strong mitogen in both Met ${ }^{\mathrm{fl} / \mathrm{fll}}$ and $\mathrm{Met}^{-/-}$oval cells, causing a 4-6 fold increase in the proliferation rate. The effect of EGF was completely abolished when EGFR activity was inhibited by treatment with the EGFR specific inhibitor, AG1478 (5 $\mu \mathrm{M})$. Interestingly, basal oval cell DNA synthesis was also drastically reduced in the presence of the inhibitor, indicating that both basal and EGF-induced oval cell DNA synthesis in vitro depend on the tyrosine kinase activity of EGFR. Furthermore, AG1478 induced an increase in the apoptosis rate of serum-deprived Met ${ }^{f|f| f l x}$ and $\mathrm{Met}^{-/-}$oval cells (Fig. 2B). The total apoptotic index under AG1478 treatment was mild-to-moderate but the observed increase over untreated cells was statistically significant. Particularly remarkable was the significantly higher apoptotic index in AG1478-treated $\mathrm{Met}^{-/-}$cells as compared to Mef $^{f \mid / f f l x}$ cells. Consistent with an increase in the apoptosis rate, AG1478-treated oval cells showed elevated caspase-3 activity over control untreated cells. Moreover, accordingly to apoptotic index data, the AG1478-induced increase in caspase-3 activity was significantly stronger and more persistent in $\mathrm{Met}^{-1 /}$ cells (Fig. 2C). These results suggest that an autocrine signalling through EGFR operates in oval cells to promote cell proliferation and survival. Our data also suggest that in the absence of c-Met-driven survival signals oval cells become more dependent on the pro-survival activity of EGFR.

Previously, we have reported that TGF- $\beta$ induces apoptosis in oval cells and that lack of c-Met tyrosine kinase activity makes oval cells more sensitive to the pro-apoptotic effects of this cytokine [16]. To gain greater insights into the 
EGFR-driven antiapoptotic activity, we also tested the effect of AG1478 on TGF$\beta$-treated oval cells. As seen in fig. 2D, AG1478 significantly amplified TGF- $\beta$ induced apoptosis both in $\mathrm{Met}^{\mathrm{fl} / \mathrm{fl} \mathrm{Ix}}$ and $\mathrm{Met}^{-/-}$cells, reaching average apoptotic indices of $35.6 \pm 9.3$ and $48.2 \pm 12 \%$, respectively, after 48 hours of treatment. It is worth noting that apoptotic indices consistently reached higher values in $\mathrm{Met}^{-{ }^{--}}$ oval cells. However, differences between $\mathrm{Met}^{\mathrm{fl} / \mathrm{fl} x}$ and $\mathrm{Met}^{-/-}$cells did not reach statistical significance. Regardless of this, and similar to what we have previously described in hepatocytes and hepatoma cells $[25,26]$, our data support a critical role for EGFR in protecting against TGF- $\beta$-induced apoptosis in oval cells.

3.3. Lack of Met-EGFR signalling cross-activation in mouse oval cells.

We have shown that both Met and EGFR trigger proliferative and antiapoptotic signals in oval cells. Increasing evidence in the literature has reported crosstalk between c-Met and EGFR. The mechanistic nature of such crosstalk is very complex, and depends on the particular cell system and the physiological/pathological context. Thus, it might occur directly or indirectly, involve different levels of interaction, and can have additive or antagonistic effects [19]. On this basis, we investigated whether EGFR may play a role in cMet-dependent signalling in oval cells and vice versa.

Since EGFR is known to transactivate c-Met [27-29], and HGF can activate EGFR [30], we first examined whether the exposure to exogenous HGF increases phosphorylation of EGFR. Cells were treated for $10 \mathrm{~min}$ with $40 \mathrm{ng} / \mathrm{ml}$ of HGF and then harvested to analyze phosphorylation and activation of EGFR and downstream signalling molecules, such as AKT and ERK 1/2. Cells treated for $10 \mathrm{~min}$ with $20 \mathrm{ng} / \mathrm{ml}$ of EGF were used as positive control for EGFR activation. Addition of EGF, but not HGF, resulted in EGFR phosphorylation both in $\mathrm{Met}^{\mathrm{fl} / \mathrm{ffl}}$ and $\mathrm{Met}^{-/-}$cells (Fig. 3A). However, phosphorylated AKT and ERK1/2 
were observed under both treatments, which is consistent with the fact that these kinases are downstream signalling molecules shared by EGFR and c-Met. The activation of AKT and ERK 1/2 by HGF occurred in Met $^{f \mid f / f l x}$, but not Met ${ }^{-1-}$, oval cells. Cumulatively, these results show that EGF and HGF trigger common signalling pathways in mouse oval cells, through their respective receptors, EGFR and Met. It should be noted that although levels of phosphorylated EGFR appeared higher in Met ${ }^{f|x| f \mid x}$ cells, a thorough analysis revealed no consistent differential EGFR phosphorylation pattern. Moreover, the levels of phosphorylated EGFR did not correlate with the levels of activation of target signalling molecules, AKT and ERK 1/2, thus discarding the possibility of a diminished EGFR-triggered signalling in $\mathrm{Met}^{-/-}$oval cells due to the absence of cMet tyrosine kinase activity.

To analyze whether EGF was able to drive c-Met activation, cells were treated in the same way and subsequently c-Met phosphorylation was detected by immunoprecipitation from cell lysates with anti-c-Met antibody, followed by western blot analysis with anti-phosphotyrosine antibody. Phosphorylated c-Met was readily detected in Met ${ }^{\text {flxflx }}$ cells treated with HGF, but not with EGF (Fig. 3B). As expected, no phosphorylated c-Met was seen in $\mathrm{Met}^{-/}$cells, regardless of the treatment used.

Altogether, these observations demonstrate that neither HGF induces EGFR tyrosine phosphorylation nor EGF phosphorylates c-Met, in mouse oval cells. Our finding that EGFR signals through AKT and ERK $1 / 2$ in oval cells with or without Met kinase activity, Met ${ }^{f \mid f / f l x}$ and Met $^{-1-}$, respectively (Fig. $3 \mathrm{~A}$ ), coupled with the fact that the EGF-induced mitogenic effect in $\mathrm{Met}^{-{ }^{-}}$oval cell is indistinguishable from that induced in Mef ${ }^{\text {fl/fflx }}$ cells (Fig. 2A) provide solid evidence that EGF-triggered signalling and biological responses in oval cells do not require a functional Met tyrosine kinase. To further validate this hypothesis, we ought to compare the anti-apoptotic activity of EGF against TGF- $\beta$ in our 
cells. As shown in Fig. 4, EGF was able to completely abolish TGF- $\beta$-induced apoptosis in Met $\mathrm{fl}^{\mathrm{fl} / \mathrm{flx}}$ as well as Met ${ }^{-/}$oval cells. In conclusion, our analyses show that Met tyrosine kinase is dispensable for EGFR-driven proliferation and survival in mouse oval cells.

3.4. HGF-induced mitogenic and survival activities in mouse oval cells are independent from EGFR kinase activity.

Although bidirectional cross-talk between Met and EGFR might occur, a role for EGFR in Met-mediated signalling seems to be more established, particularly in hepatic cells $[17,18,28]$. Hence, we next tested the consequences of inhibiting the EGFR kinase on HGF-driven signalling. As seen in Fig. 5A, activation of Akt, ERK 1/2, and STAT3 by HGF in Met ${ }^{f \mid f f f l}$ oval cells was not reduced nor inhibited in the presence of AG1478, whereas it completely abolished activation of EGFR downstream signalling pathways (AKT, ERK 1/2) in EGF-stimulated cells (Fig. 5B). These results indicate that AKT and ERK 1/2 signalling downstream of c-Met activation occurs independently of EGFR activation.

We have previously reported that HGF elicits mitogenic and anti-apoptotic activities in mouse oval cells [16]. To unequivocally assess whether or not EGFR kinase contributes to HGF-mediated activities in oval cells, we chose to analyze the effects of the inhibitor AG1478 on HGF-driven proliferation and survival. If a total or partial dependence on EGFR activity existed, an inhibition or decrease of those effects should be expected upon inhibition of EGFR. Instead, HGF-elicited increase in DNA synthesis was preserved in spite of EGFR inhibition (Fig. 6A). EGF-treated cells were used as positive control for the specificity and efficacy of the inhibitor. AG1478 completely prevented EGF-mediated enhancement in DNA synthesis as anticipated. 
A similar approach was used for the analysis of the effect of EGFR inhibition on HGF-mediated protection against TGF- $\beta$-induced apoptosis. We have previously described that addition of exogenous HGF resulted in an approximate $50 \%$ decrease in the TGF- $\beta$-induced apoptosis [16]. The same decrease was observed when AG1478 was present (Fig. 6B), demonstrating that the EGFR kinase is not required for the HGF pro-survival activity in oval cells.

As an additional approach to further confirm these results we silenced the expression of EGFR with siRNAs. As shown in supplementary figure 1A, a high silencing efficiency was reached based on the almost complete disappearance of the EGFR protein. Consistent with the AG1478 data, EGFR knockdown did not prevent HGF-induced activation of target signals, ERK1/2 and AKT (suppl.

Fig.1B). Furthermore, neither the HGF-mediated increase in DNA synthesis nor the protection against TGF- $\beta$-induced apoptosis, were affected by EGFR silencing (suppl. Fig. 1C,D).

These studies together demonstrate that c-Met and EGFR promote proliferation and survival of mouse oval cells independent of one another.

\section{Discussion}

The signalling pathways that control oval cell biology are only poorly understood. In this study we have directly approached the relevance of EGFRmediated signaling for mouse oval cell proliferation and survival in vitro. In addition to this, we have analyzed whether a functional dependency exists between the two RTKs, EGFR and c-Met, for controlling such responses. Our results show an autocrine EGFR activation in mouse oval cells that promotes proliferation and survival. Furthermore, we demonstrate that neither EGFR requires c-Met activity nor c-Met requires EGFR activity to elicit their mitogenic and anti-apoptotic functions in oval cells. 
It is well known that the EGFR and its ligands play a critical role in the proliferative response accompanying liver regeneration after partial hepatectomy [23]. In fact, mice lacking EGFR showed a delay in liver regeneration due to a reduced hepatocyte proliferation and cell cycle progression [31]. In contrast, scarce data is available in the literature regarding EGFR signalling in progenitormediated liver regeneration. The fact that infusion of TGF- $\alpha$ increases oval cell proliferation after 2-AAF/PH protocol [15] suggested that EGFR signalling is also an important regulator of liver progenitor cells proliferation in a regenerative context, but for now, the impact of deleting EGFR signalling in liver regeneration from oval progenitor cells remains undefined. Interestingly, TGF- $\alpha$ transcripts are undetectable or very low in normal liver or non-replicating hepatocytes, but are up-regulated in hepatocytes during partial hepatectomy and toxic injury $[32,33]$ as well as in proliferating oval cells and basophilic foci of hepatocytes in regenerating liver induced by a modified Solt-Farber protocol [12], providing indirect evidence for the implication of an autocrine mechanism. Here, using in vitro approaches we present the first direct evidence of the autocrine action of EGFR ligands in non-tumorigenic oval cells. This is supported by constitutive expression of EGFR ligands (Fig. 1A) and activation of EGFR (Fig. 1B); as well as a decrease in basal proliferation rate and increased apoptosis upon inhibition of EGFR kinase (Fig. 2). Remarkably, the EGFR inhibitor almost completely inhibits endogenous oval cell proliferation (Fig. 2A), resembling the response seen in hepatoma cells [34]. Similar results have also been reported in adult rat hepatocytes [18] using PKI166, a dual EGFR/ErbB2 inhibitor, although the inhibitory effect was not as strong as that observed in oval cells using AG1478. More importantly, the presence of c-Met tyrosine kinase cannot override the potent inhibitory effect of AG1478 on cell proliferation (Fig. 2A). This, together with our previous results showing that lack of c-Met tyrosine kinase activity has no effect on oval cell proliferation [16], strongly suggest a major role for EGFR in regulation of oval cell proliferation. 
It is well known that EGFR-dependent signalling integrates proliferative and survival signals in hepatocytes. Indeed, we and others have previously reported that EGF induces proliferation [20] and protects hepatocytes from various apoptotic insults, including TGF- $\beta$, Fas, and deoxycholic acid $[25,35,36]$. Furthermore, EGFR is activated and required for TGF- $\beta$-induction of antiapoptotic signals, such as AKT [22], constituting a part of the mechanism induced by TGF- $\beta$ to confer resistance to apoptosis in fetal hepatocytes after an EMT process [37]. Consistent with these data, we see an increased apoptotic index under serum deprivation as well as TGF- $\beta$ treatment in the presence of AG1478 (Fig. 2B-D). We have not explored in detail the mechanisms involved in the EGFR autocrine antiapoptotic signalling in oval cells. However, we see a notable decrease in TGF- $\alpha$ mRNA levels under AG1478 treatment (data not shown), which indicates that EGFR kinase activity is required for the induction of the expression of EGFR ligands, thus activating a pro-survival amplifying loop. On the other hand, the lower apoptosis levels displayed by serum-deprived Met $^{f \mid f / f l x}$ cells in the presence of AG1478 are consistent with an active Metdependent autocrine survival signalling in Met ${ }^{f \mid f / f l x}$ oval cells [16], and serve as an additional proof for the capacity of c-Met signalling to restrain the apoptotic response in oval cells. It should be pointed out that EGFR silencing did not result in an amplification of the apoptotic response in oval cells (suppl. Fig.1D). This result was not at all surprising since we have recently described that AG1478 has broader effects than EGFR silencing on apoptosis in hepatocellular carcinoma cells [38]. These observations make clear that AG1478 might have both EGFRdependent and independent effects, and leave the door open to future studies to explore additional targets, including other members of the ErbB receptor family. Taken altogether, our results constitute compelling evidence for a regulation of oval cell growth and survival by autocrine growth factors, i.e., HGF and EGFR ligands. At the same time, they highlight non-redundant roles for autocrine EGFR 
and c-Met signalling in oval cell proliferation and survival. While EGFR seems to be more important for driving proliferation, both RTKs might cooperate to protect cells against apoptotic insults. Nonetheless, c-Met appears to have some unique effects on promoting cell survival, which would explain why EGFR is not able to compensate for c-Met loss.

It is of particular interest that EGF is able to protect against TGF- $\beta$-induced apoptosis regardless the presence or absence of a functional c-Met (Fig. 4). These data indirectly suggests that EGFR-mediated antiapoptotic signalling operating in oval cells is independent of Met tyrosine kinase activity. The communication between Met and EGFR and its functional consequences has been a major subject of debate during many years. Different mechanisms, alone or in combination, might mediate direct and indirect crosstalk between these receptor systems. Such mechanisms include physical interaction between receptors, ligand-mediated transactivation of the receptors, or induction of ligand gene transcription [19]. In this study, we have tested whether one or several of these mechanisms operate in oval cells. Results demonstrate that in oval cells EGFR is activated by EGF, but not HGF, and c-Met is activated by HGF, but not EGF (Figure 3), which indicates that no ligand-induced transphosphorylation between c-Met and EGFR occurs. Moreover, inhibition of EGFR activity by AG1478 treatment or siRNA-mediated EGFR gene silencing has no effect on ligand-mediated activation of c-Met downstream targets (Fig.5A and suppl. Fig.1B). Our results are in agreement with data from primary rat hepatocytes showing that only HGF but not EGF drives c-Met phosphorylation and EGFR inhibition does not affect HGF-induced c-Met activation [18]. However, differently from oval cells, either inhibition of EGFR activity [18] or TGF- $\alpha$ synthesis and activity [17], block the mitogenic effect of HGF on hepatocytes. This, together with results indicating the capability of HGF to induce TGF- $\alpha$ mRNA transcription in HepG2 cells [39], suggests that in normal and tumorigenic hepatocytes, HGF might promote hepatocyte proliferation in an EGFR-dependent manner through 
the production of EGFR ligands. A similar transcription-dependent crosstalk between c-Met and EGFR has been established in several cell types, including malignant and untransformed cells $[30,40]$, where it is required for induction of cell proliferation or motility. We prove here that this mechanism does not work in oval cells, where EGFR is not required for HGF/c-Met-driven signalling (Fig.5A and suppl. Fig.1B) and mitogenic and anti-apoptotic activities (Fig. 6A,B and suppl. Fig.1C,D), hence discarding any role for EGFR in the HGF-triggered effects in oval cells. Altogether, these findings make it clear that communication between EGFR and c-Met and the mechanisms involved are cell and context dependent, revealing an enormous plasticity of the cell signalling mechanisms, which allow cells to adjust to the continuously variable environment. Additionally, in spite of the apparent prevalent role in oncogenesis, cross-talk between c-Met and EGFR might also be relevant in some particular non-tumorigenic contexts, e.g. development, tissue homeostasis and regeneration, where crosstalk within signalling networks might be crucial for the control of proliferation, survival, and motility processes, and ultimately for successful completion of any of these programs. Why HGF does not use EGFR as part of the signalling cascade activated in oval cells to induce cell proliferation or survival remains unclear. Certainly, communication between the two RTKs could be beneficial as it provides additional signalling platforms to control cell response and fate. It might be that EGFR had a less central role in oval cell regulation than it has on hepatocytes and other epithelial cells. Likewise, c-Met might have other preferred partners, among the multiple membrane proteins with whom it can interact [19]. From a different perspective, the fact that HGF does not require EGFR kinase activation to promote its actions can be seen as a sign of a more dominant role for c-Met in oval cells, which is able to trigger cell responses regardless of whether EGFR is functional or not.

It is plausible that the EGFR-Met crosstalk could gain relevance in transformed oval cells, where crosstalk might be important to amplify RTK 
signaling and contribute to cell transformation. Accordingly, overexpression of TGF- $\alpha$ in normal rat liver epithelial cells (RLEC) and tumor clones derived from them results in phosphorylation of c-Met in the absence of HGF [41]. Similarly, $\mathrm{HCC}$ and other tumor cell lines show constitutively phosphorylated c-Met, effect that is inhibited by neutralizing antibodies against TGF- $\alpha$ and/or EGFR or by treatment with AG1478 [28]. However, differently from oval cell lines, constitutive phosphorylation of Met in hepatocellular carcinoma ( $\mathrm{HCC}$ ) cells is not associated to the expression of the HGF transcript, but more likely to autocrine TGF- $\alpha$.

These and other studies establish a direct link between oval cell malignancy and autocrine signalling, signalling crosstalks, and alteration in growth factor responsiveness. Both HGF and TGF- $\alpha$ autocrine loops have been identified in transformed rat oval cells and close relatives, and proven to confer tumorigenic properties [42-44]. Conversely, recent studies performed using the nontumorigenic oval cell line LE6 and retroviral-mediated expression of MYC, TGF $\alpha$ or the combination of both, have demonstrated that only MYC and MYC/TGF $\alpha$ transfected oval cells, but not oval cells expressing TGF $\alpha$ alone, develop tumors when injected into nude mice [45]. Furthermore, our results have also shown that non-tumorigenic oval cells display autocrine activation of c-Met [16] and EGFR tyrosine kinases (Fig. 1B). Therefore, it seems that TGF $\alpha / E G F R$ or HGF/c-Met autocrine loops are not generally sufficient to promote oval cell transformation. It might certainly be one common feature in transformed immature epithelial cells and contribute to support autocrine growth of liver tumor cells but neoplastic transformation requires additional critical partners.

In conclusion, EGFR and c-Met drive common biological responses, such as mitogenesis and protection against apoptosis, in oval cells. However, results suggest distinct non-overlapping roles for EGFR and c-Met. Thus, in spite of the capacity of both receptors to induce mitogenic and survival signals, EGFR seems to be a more efficient and relevant mitogenic signal than c-Met, whereas c-Met appears to have some unique and prevalent effects as a pro-survival signal. In addition, although our results do not at all rule out that EGFR and c-Met can act 
cooperatively and/or coordinately to promote these activities in specific contexts, they show that neither of the two RTKs depends on each other activity. Important questions remain open concerning whether EGFR-c-Met crosstalk would be activated upon transformation of oval cells and contribute to HCC development or progression. Certainly, the lack of RTKs promiscuity could very well constitute a safekeeper mechanism to protect oval cells from malignant conversion.

\section{Acknowledgements}

A. Martínez-Palacián is recipient of a research-training contract (associated with grant SAF2006-12025) from the Ministry of Education and Science. G. del Castillo was recipient of a research-training contract from the Ministry of Education and Science.

We express appreciation to Dr. S.S. Thorgeirsson and Dr. V.M.Factor for generously providing the c-met conditional knockout mouse-derived parental oval cells, from which the Met ${ }^{f|x| f \mid x}$ and $\mathrm{Met}^{-/}$oval cell clones were generated. We also acknowledge Dr. A. Porras for helpful discussions.

\section{Role of the funding source}

This work has been supported by grants SAF2006-12025 from Ministry of Education and Science (Spain), SAF2009-12477 from Ministry of Science and Innovation (Spain), and 920359 (CAM-UCM, BSCH-UCM). The funding sources have not been involved in the study design, development, or in the preparation of the manuscript and decision to submit the manuscript for publication.

\section{Citations}

[1] A.W. Duncan, C. Dorrell, M. Grompe, Gastroenterology 137 (2) (2009) 466481. 
[2] G.K. Michalopoulos, Int. J. Biochem. Cell Biol. 43 (2) (2009) 173-179.

[3] M.R. Alison, S. Islam, S. Lim, J. Pathol. 217 (2) (2009) 282-298.

[4] L. Mishra, T. Banker, J. Murray, S. Byers, A. Thenappan, A.R. He, K. Shetty, L. Johnson, E.P. Reddy, Hepatology 49 (1) (2009) 318-329.

[5] M. Sibilia, R. Kroismayr, B.M. Lichtenberger, A. Natarajan, M. Hecking, M. Holcmann, Differentiation 75 (9) (2007) 770-787.

[6] M.R. Schneider, E. Wolf, J. Cell Physiol. 218 (3) (2009) 460-466.

[7] L. Trusolino, A. Bertotti, P.M. Comoglio, Nat. Rev. Mol. Cell Biol. 11 (12) (2010) 834-848.

[8] T. Nakamura, K. Sakai, T. Nakamura, K. Matsumoto, J. Gastroenterol. Hepatol. 26 Suppl. 1 (2011) 188-202.

[9] K.A.Furge, Y-W. Zhang, G.F.Vande Woude, Oncogene 19 (49) (2000) 55825589.

[10] N. Prenzel, O. M. Fischer, S. Streit, S. Hart, A. Ullrich, Endocrine-Related Cancer 8 (1) (2001) 11-31.

[11] R.N. Jorissen, F. Walker, N. Pouliot, T.P.J. Garrett, C.W. Ward, A.W. Burgess, Exp. Cell Res. 284 (1) (2003) 31-53.

[12] R.P. Evarts, H. Nakatsukasa, E.R. Marsden, Z. Hu, S.S. Thorgeirsson, Mol Carcinogenesis 5 (1) (1992) 25-31.

[13] R.P. Evarts, Z. Hu, K. Fujio, E.R. Marsden, S.S. Thorgeirsson, Cell Growth Differ. 4 (7) (1993) 555-561.

[14] Z. Hu, R.P. Evarts, K. Fujio, E.R. Marsden, S.S. Thorgeirsson, Am. J. Pathol. 142 (6) (1993) 1823-1830.

[15] P. Nagy, H.C. Bisgaard, E. Santoni-Rugiu, S.S. Thorgeirsson, Hepatology 23 (1) (1996) 71-79.

[16] G. del Castillo, V.M. Factor, M. Fernández, A. Alvarez-Barrientos, I.

Fabregat, S.S. Thorgeirsson, A. Sánchez, Am. J. Pathol. 172 (5) (2008) 12381247.

[17] T. Tomiya, I. Ogata, M. Yamaoka, M. Yanase, Y. Inoue, K. Fujiwara, Am. J. Pathol. 157 (5) (2000) 1693-1701.

[18] L.A. Scheving, M.C. Stevenson, J.M. Taylormoore, P. Traxler, W.E. Russell, Biochem. Biophys. Res. Commun. 290 (1) (2002) 197-203.

[19] A.Z. Lai, J.V. Abella, M. Park, Trends Cell Biol. 19 (10) (2009) 542-551.

[20] C. de Juan, M. Benito, A. Alvarez, I. Fabregat, Exp. Cell Res. 202 (2) (1992) 495-500.

[21] E.A. Conner, P.J. Wirth, A. Kiss, E. Santoni-Rugiu, S. S. Thorgeirsson, Biochem. Biophys. Res. Commun. 236 (2) (1997) 396-401.

[22] M.M. Murillo, G. del Castillo, A. Sánchez, M. Fernández, I. Fabregat, Oncogene 24 (28) (2005) 4580-4587.

[23] G.K. Michalopoulos, J. Cell Physiol. 213 (2) (2007) 286-300.

[24] I. Fabregat, World J. Gastroenterol. 15 (5) (2009) 513-520.

[25] I. Fabregat, A. Sanchez, A.M. Alvarez, T. Nakamura, M. Benito, FEBS Lett. 384 (1996) 14.

[26] P. Sancho, E. Bertran, L. Caja, I. Carmona-Cuenca, M.M. Murillo, I. Fabregat, Biochim. Biophys. Acta 1793 (2) (2009) 253-263. 
[27] J.D. Bergström, B. Westermark, N-E. Heldin, Exp. Cell Res. 259 (1) (2000) 293-299.

[28] M. Jo, D.B. Stolz, J.E. Esplen, K. Dorko, G.K. Michalopoulos, S.C. Strom, J. Biol. Chem. 275 (12) (2000) 8806-8811.

[29] R. Pai, T. Nakamura, W.S. Moon, A.S. Tarnawski, FASEB J. 17 (12) (2003) 1640-1647.

[30] J.K. Spix, E.Y. Chay, E.R. Block, J.K. Klarlund, Exp. Cell Res. 313 (15) (2007) 3319-3325.

[31] A. Natarajan, B. Wagner, M. Sibilia, Proc. Natl. Acad. Sci. USA 104 (43)

(2007) 17081-17086.

[32] J.E. Mead, N. Fausto, Proc. Natl. Acad. Sci. USA 86 (5) (1989) 1558-1562.

[33] E.M. Webber, M.J. FitzGerald, P.I. Brown, M.H. Bartlett, N. Fausto, Hepatology 18 (6) (1993) 1422-1431.

[34] C. Ortiz, L. Caja, P. Sancho, E. Bertran, I. Fabregat, Biochem. Pharmacol. 75 (10) (2008) 1935-1945.

[35] L. Musallam, C. Ethier, P.S. Haddad, M. Bilodeau, Am. J. Physiol. Gastrointest. Liver Physiol. 280 (6) (2001) G1360-1369.

[36] L. Qiao, E. Studer, K. Leach, R. McKinstry, S. Gupta, R. Decker, R. Kukreja, K. Valerie, P. Nagarkatti, W. el Deiry, J. Molkentin, R. Schmidt-Ullrich, P.B.

Fischer, S. Grant, P.B. Hylemon, P. Dent, Mol. Biol. Cell 12 (9) (2001) 26292645.

[37] G. del Castillo, M.M. Murillo, A. Alvarez-Barrientos, E. Bertran, M.

Fernandez, A. Sanchez, I. Fabregat, Exp. Cell Res. 312 (15) (2006) 2860-2871. [38] L. Caja, P. Sancho, E. Bertran, C. Ortiz, J.S. Campbell, N. Fausto, I. Fabregat, Biochem. Pharmacol. (2011), doi:10.1016/j.bcp.2011.08.011. [39]G. Shiota, T. Nakamura, E.V. Schmidt, Biochem. Biophys. Res. Commun. 200 (2) (1994) 1099-1104.

[40] T.E. Reznik, Y. Sang, Y. Ma, R. Abounader, E.M. Rosen, S. Xia, J. Laterra, Mol. Cancer Res. 6 (1) (2008) 139-150.

[41] S.C. Presnell, D.B. Stolz, W.M. Mars, M. Jo, G.K. Michalopoulos, S.C. Strom, Mol. Carcinog. 18 (4) (1997) 244-255.

[42] A.D. Laird, P.I. Brown, N. Fausto, Cancer Res. 54 (15) (1994), 4224-4232. [43] R.J. Isfort, D.B. Cody, W.G. Richards, B.K. Yoder, J.E. Wilkinson, R.P. Woychik, Growth Factors 15 (2) (1998) 81-94.

[44] S.C. Presnell, M.J. Hooth, K.M. Borchert, W.B. Coleman, J.W. Grisham, G.J. Smith, Hepatology 28 (5) (1998) 1253-1259.

[45] R.S. Cheung, J.T. Brooling, M.M. Johnson, K.J. Riehle, J.S. Campbell, N. Fausto, Carcinogenesis 28 (12) (2007) 2624-2631.

\section{Figure legends}

Figure 1. Constitutive expression of EGFR ligands and activation of EGFR in 
mouse $\mathrm{Met}^{\mathrm{fl} / \mathrm{fl} \mathrm{lx}}$ and $\mathrm{Met}^{-/-}$oval cell lines. (A) EGFR ligands mRNA expression was analyzed by RT-PCR in oval cells cultured for $24 \mathrm{~h}$ in the absence or presence of $10 \%$ FBS. $\beta$-actin was used for normalization. RT-: no reverse transcription. (B) Oval cells were serum-starved for $12 \mathrm{~h}$ and then treated with EGF $(20 \mathrm{ng} / \mathrm{ml})$ for $5 \mathrm{~min}$. Cell lysates were immunoprecipitated with antiphosphotyrosine antibody and blotted with anti-EGFR antibody. Neg.: negative control (no primary antibody). Sup.: positive control (IP input), supernatants collected after immunoprecipitation from the same lysates.

Figure 2. Effect of EGFR inhibition with AG1478 on mouse Met ${ }^{\mathrm{fl} / \mathrm{fl|} x}$ and $\mathrm{Met}^{-{ }^{-}}$ oval cells proliferation and apoptosis. (A) DNA synthesis as determined by thymidine incorporation in oval cells cultured for $48 \mathrm{~h}$ in the absence or presence of EGF $(20 \mathrm{ng} / \mathrm{ml})$ pretreated or not with AG1478 $(5 \mu \mathrm{M})$ for $30 \mathrm{~min}$. Data are mean \pm SEM of three independent experiments. ${ }^{*} P<0.05$. ${ }^{* * \star} P<0.001$. (B) Apoptotic index in oval cells treated with $5 \mu \mathrm{M}$ AG1478 for the indicated times. Apoptotic nuclei were visualized and counted after PI staining under a fluorescence microscope in a blinded manner. A minimum of 1000 cells was counted per dish. Data are mean \pm SEM of six independent experiments. ${ }^{*} P<$ 0.05. (C) Kinetics of caspase-3 activity in oval cells treated with $5 \mu$ M AG1478. Data are mean \pm SEM of six independent experiments. ${ }^{*} P<0.05$. ${ }^{* *} P<0.01$. (D) Apoptotic index in oval cells treated with TGF- $\beta(1 \mathrm{ng} / \mathrm{ml})$ with or without pretreatment with AG1478. Apoptotic nuclei were visualized and counted as in (B). Data are mean \pm SEM of six independent experiments. ${ }^{*} P<0.05$.

Figure 3. Ligand-induced Met and EGFR phosphorylation in mouse oval cells. (A) Mouse Met ${ }^{f \mid x / f l x}$ and $\mathrm{Met}^{-/-}$oval cell lines were serum-starved and treated with EGF $(20 \mathrm{ng} / \mathrm{ml})$ or HGF $(40 \mathrm{ng} / \mathrm{ml})$ for $10 \mathrm{~min}$. Untreated cells were included as control. Whole cell lysates were collected and used for immunoblotting with 
antibodies against phosphorylated EGFR and downstream signaling molecules (AKT, ERK 1/2). (B) Cells were cultured as in (A). Whole cell lysates were collected for immunoprecipitation with c-Met antibody, followed by immunoblotting with anti-phosphotyrosine (4G10) and anti-Met (sc-162) antibodies. Mock: control IP without antibody.

Figure 4. EGF-induced protection against TGF- $\beta$-induced apoptosis in mouse $\mathrm{Met}^{\mathrm{fl} / \mathrm{fll} x}$ and $\mathrm{Met}^{-{ }^{-}-}$oval cell lines. Cells were treated with $1 \mathrm{ng} / \mathrm{ml}$ TGF- $\beta$ alone or with $20 \mathrm{ng} / \mathrm{ml} \mathrm{EGF}$ for 48 hours. Apoptotic index was measured as indicated before. Data are mean \pm SEM of two independent experiments run in triplicates. ${ }^{* * *} P<0.001$. Black bars, Met ${ }^{f|x| f \mid x}$ cells. White bars, Met ${ }^{-1 /}$ cells.

Figure 5. Comparison of the HGF-induced signalling in mouse oval cells in the absence or presence of an EGFR tyrosine kinase inhibitor. (A) Mouse Met ${ }^{f \mid \mathrm{f} / \mathrm{fl} x}$ oval cell lines were serum-starved and treated with HGF $(40 \mathrm{ng} / \mathrm{ml})$ for different periods of time. Where indicated, $5 \mu \mathrm{M}$ AG1478 was added for $30 \mathrm{~min}$ before treatment. Whole cell lysates were immunoblotted with the indicated antibodies. $\beta$-actin was used for normalization. (B) Mouse Met ${ }^{f|l| f \mid x}$ and $\mathrm{Met}^{-{ }^{-}}$oval cell lines were treated with EGF $(20 \mathrm{ng} / \mathrm{ml})$ for 10 min with or without pretreatment with AG1478 (5 $\mu \mathrm{M})$ and processed similarly to those in (A).

Figure 6. Effect of EGFR inhibition on HGF-induced proliferative and survival activities in mouse oval cells. (A) DNA synthesis as determined by thymidine incorporation in oval cells cultured for $48 \mathrm{~h}$ with $20 \mathrm{ng} / \mathrm{ml} \mathrm{EGF}$ or $40 \mathrm{ng} / \mathrm{ml} \mathrm{HGF}$ after 30 min of pretreatment with $5 \mu M$ AG1478. Data are mean \pm SEM of two independent experiments run in triplicates. ${ }^{* *} P<0.01$. Black bars, Met ${ }^{\mathrm{fl} / \mathrm{fl} \mid \mathrm{x}}$ cells. White bars, Met ${ }^{-/}$cells. (B) Apoptotic index in oval cells treated with $1 \mathrm{ng} / \mathrm{ml}$ TGF$\beta$ alone or with $40 \mathrm{ng} / \mathrm{ml} \mathrm{HGF}$ for $24 \mathrm{~h}$ with or without pretreatment with $5 \mu \mathrm{M}$ 
AG1478. Apoptotic nuclei were visualized and counted as in figure 2B and 2D. Data are mean \pm SEM of two independent experiments run in triplicates. ${ }^{* * *} P<$ 0.001. Black bars, Met ${ }^{f \mid \mathrm{f} / \mathrm{flx}}$ cells. White bars, $\mathrm{Met}^{-/}$cells.

\section{Disclosure Statements}

The authors state no conflicts of interest. All authors have participated in the research and/or article preparation. A. Martínez-Palacián, G. del Castillo, and $B$. Herrera have been involved in the execution of experiments and data analysis. M. Fernández; C. Roncero, and I. Fabregat helped in the experimental design, analysis and interpretation of data, and reviewing the draft of the manuscript. A. Sánchez designed the study, analyzed and interpreted the data, and wrote the manuscript. All authors approve the final version of the manuscript to be published. 


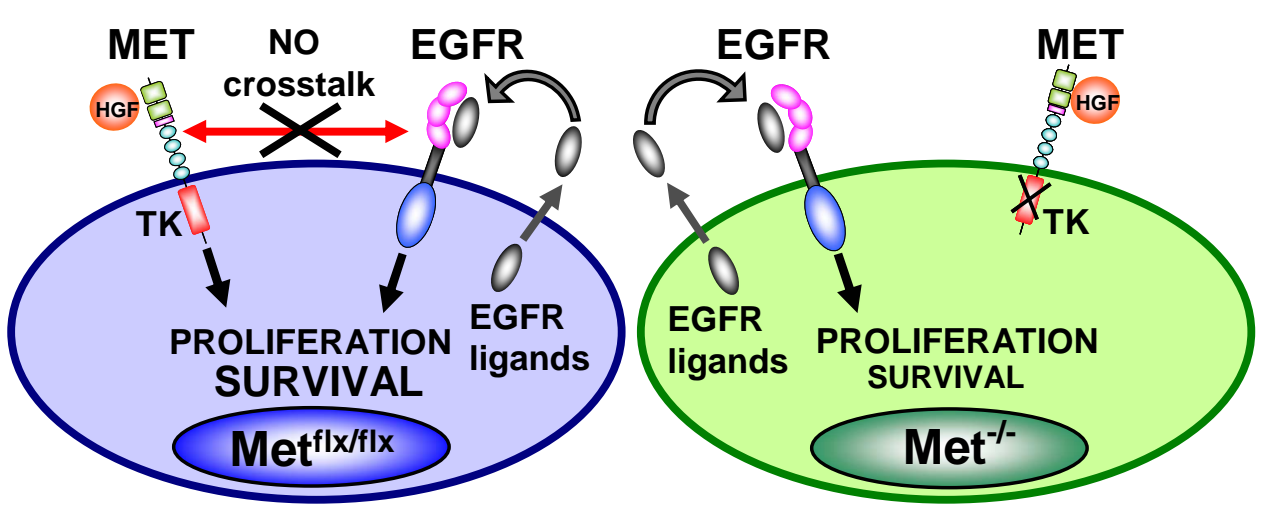


- Constituvely activated EGFR promotes mouse oval cells proliferation and survival

- EGFR signalling does not depend on c-Met tyrosine kinase activity

- c-Met signalling does not require EGFR activation to mediate proliferation and survival 
A

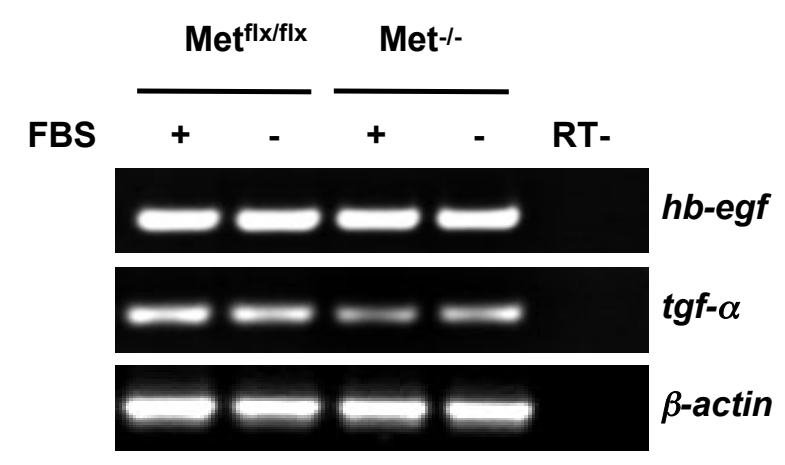

B

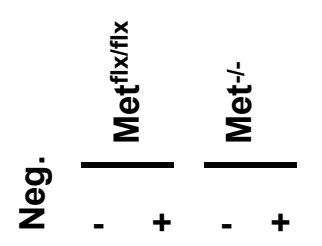

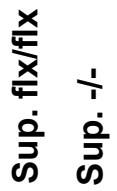
- - EGF

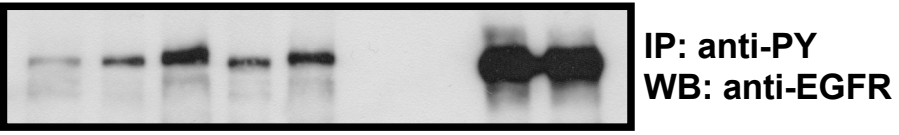
WB: anti-EGFR

Figure 1.

A 
Figure 2.

A

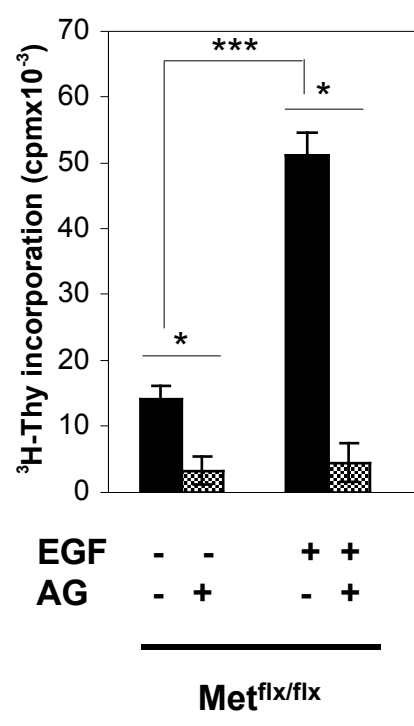

C

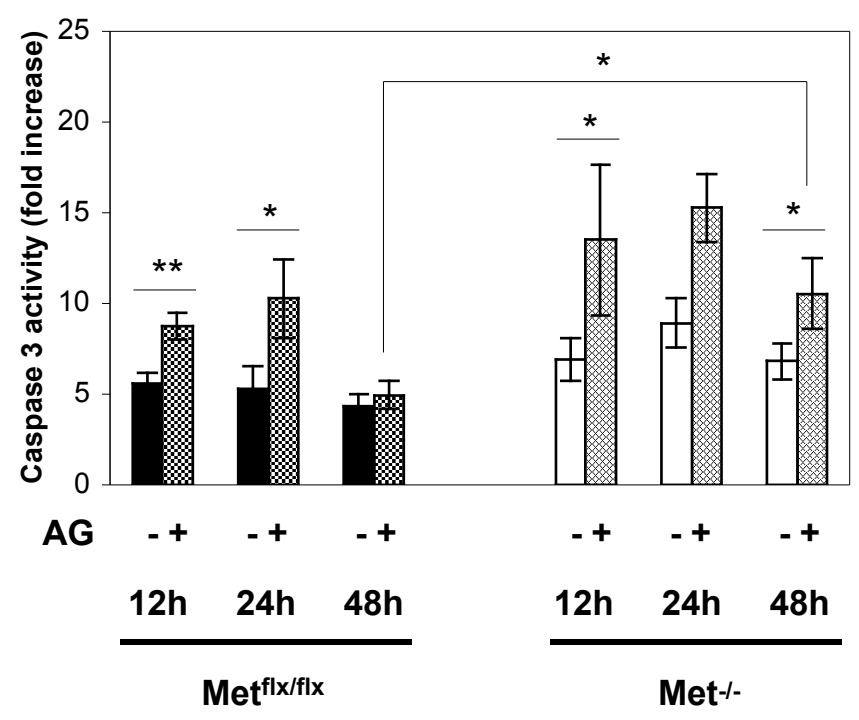

B

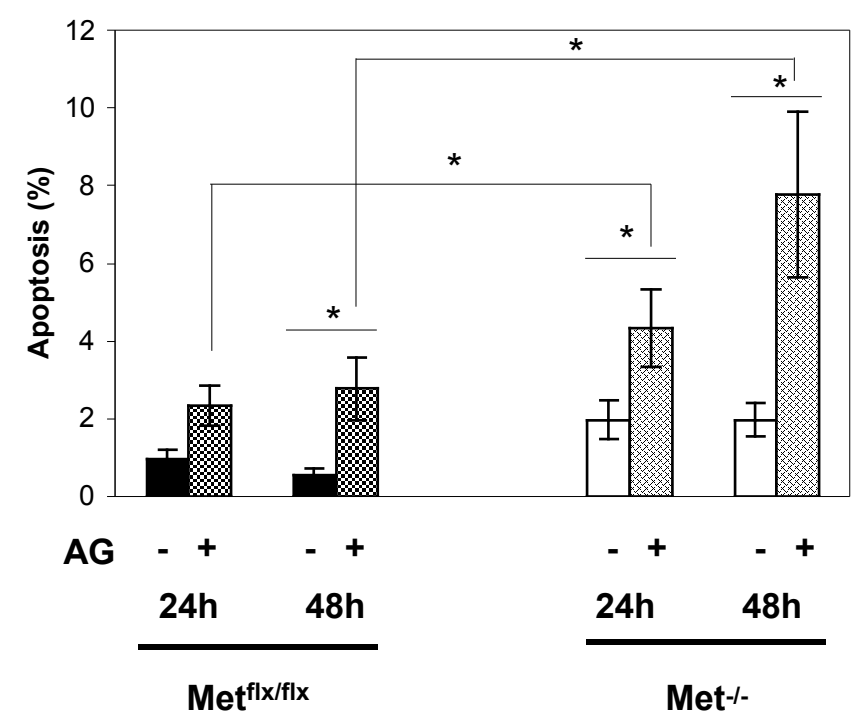

D

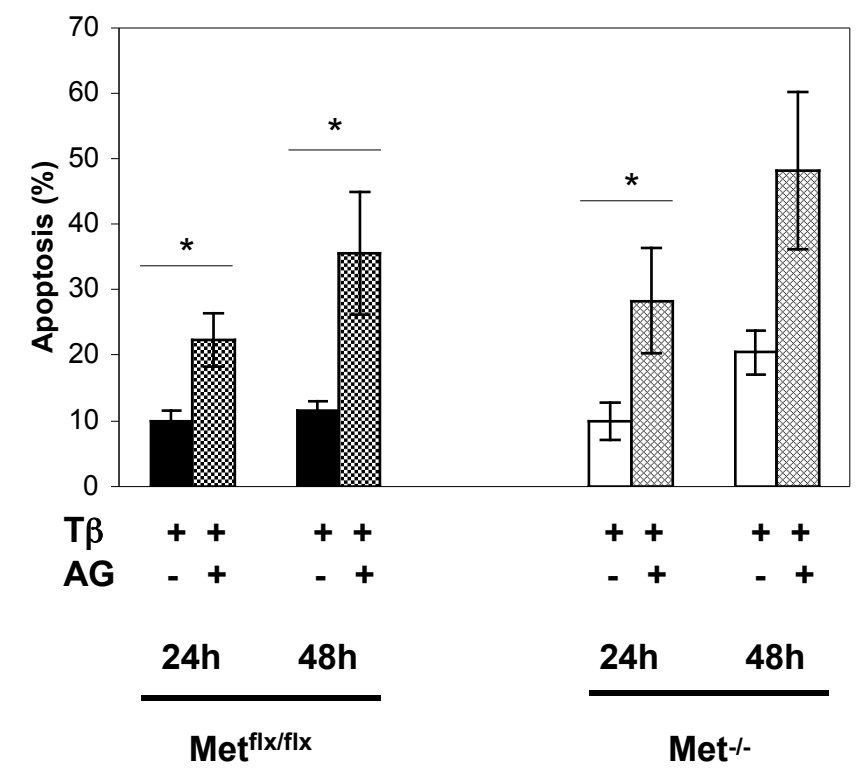


Figure 3.

A

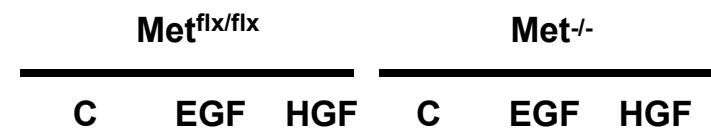
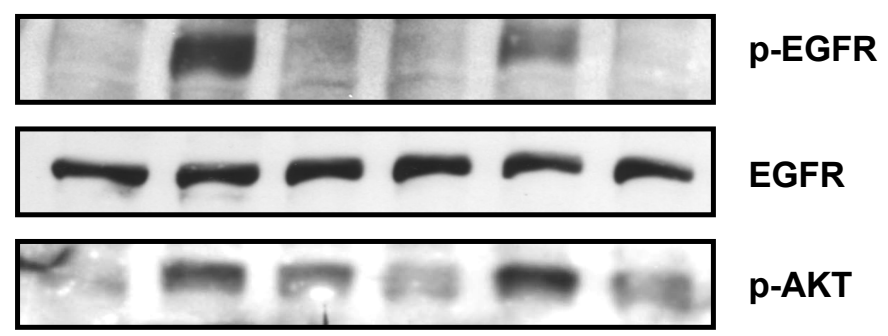

ש

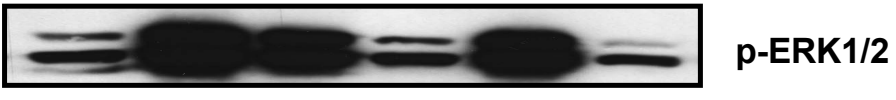

$\mathrm{Em} \equiv \mathrm{ERK} 1 / 2$

B

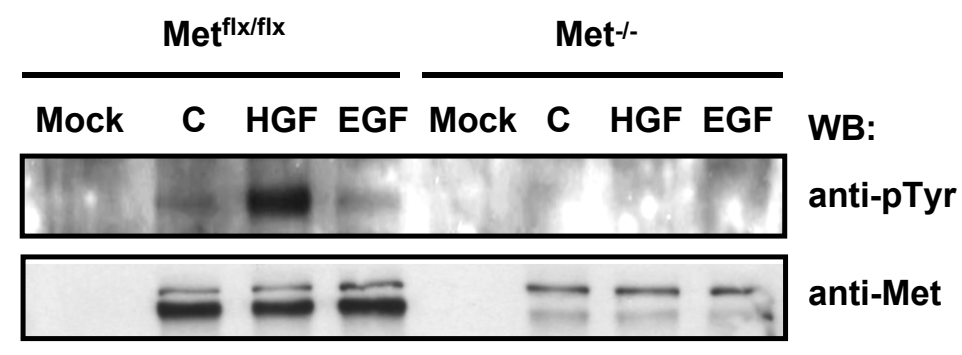

IP: anti-Met 
Figure(s)

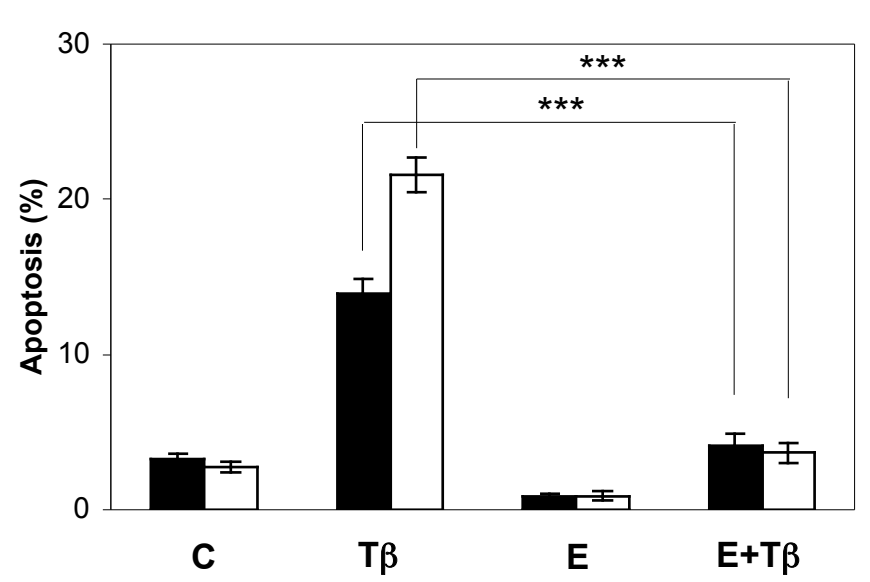

Figure 4. 
Figure 5.

A

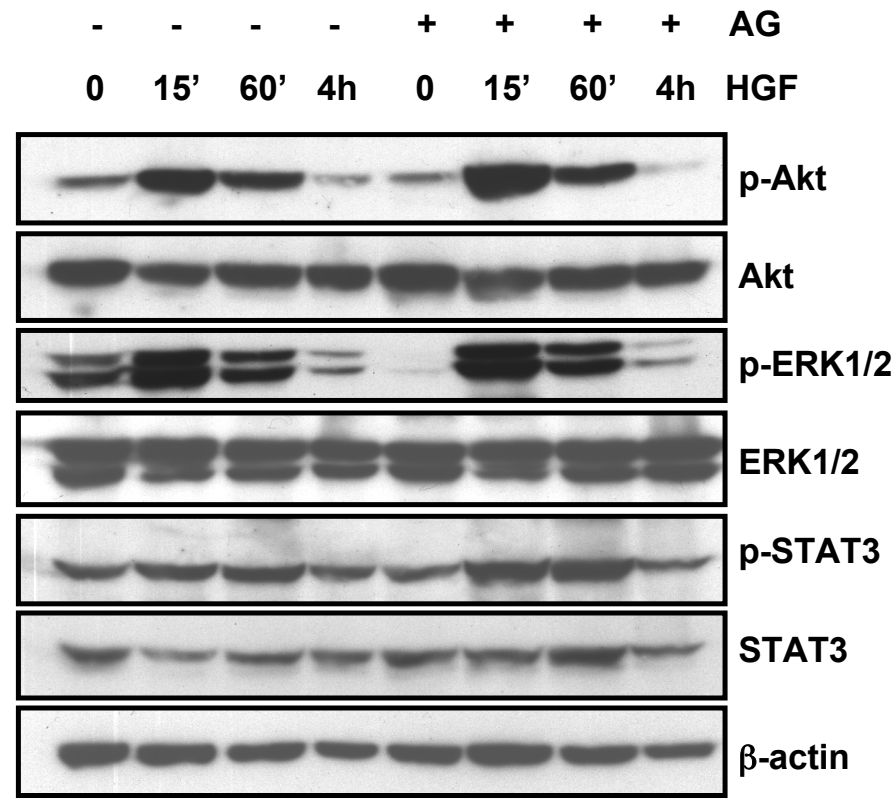

B

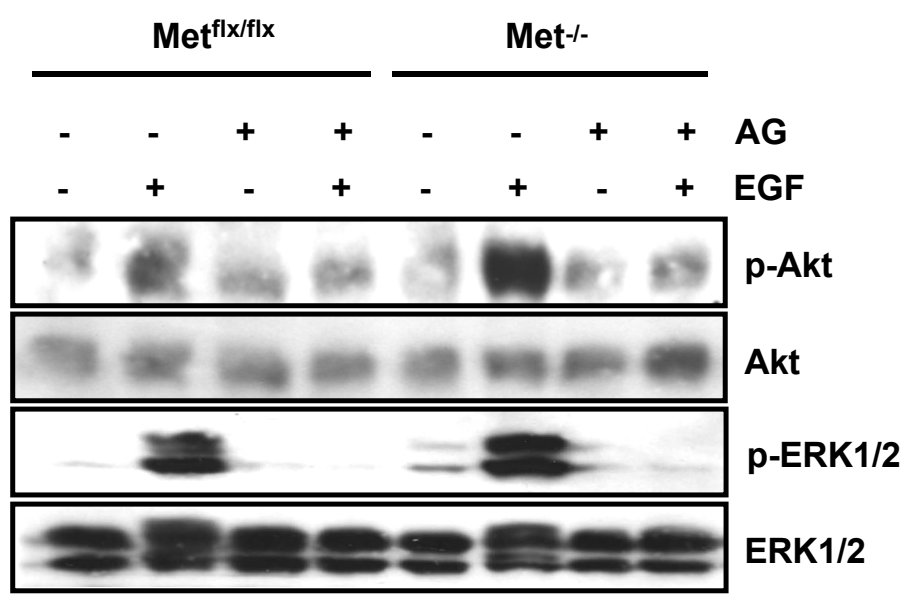


Figure 6.

A

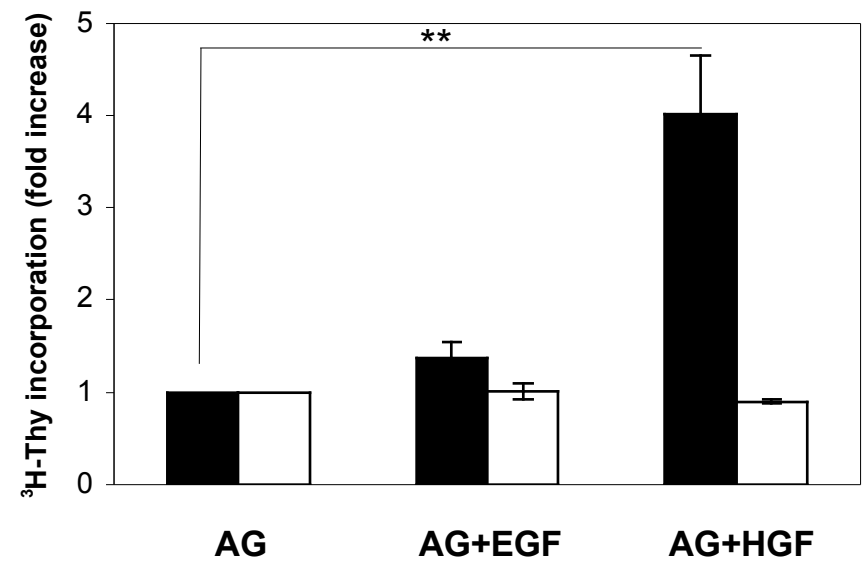

B

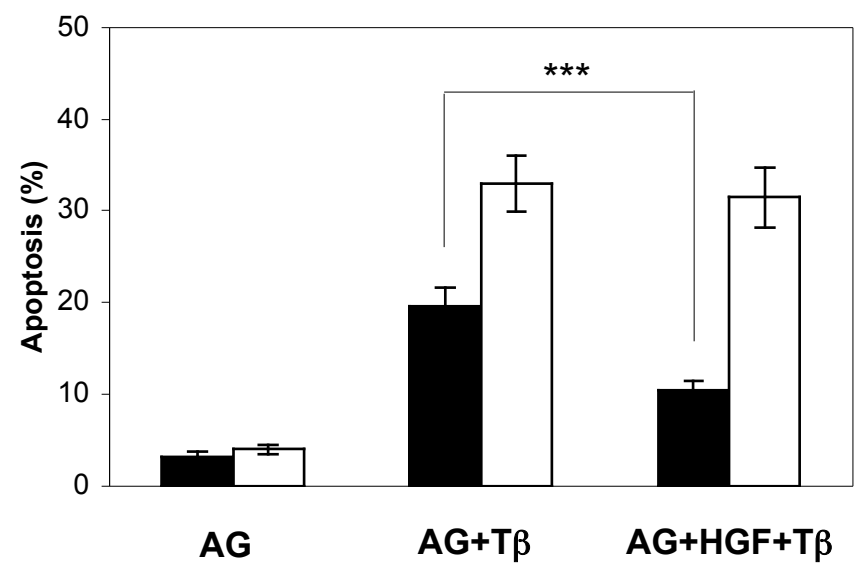


Click here to download Supplementary Material: Supplementary Data.pdf

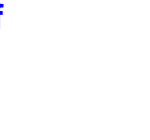

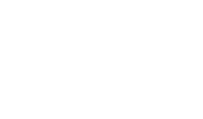


Click here to download Supplementary Material: Supplementary Figure.pdf Supplementary Material
Click here to download S Clin 


\section{Supplementary material and methods}

\section{siRNA knockdown assays}

For transient siRNA transfection, cells were seeded at 50-60\% confluence. On the following day, cells were transfected with the mouse EGFR SMARTpool siRNA (50nM) or the control non-targeting siRNA (50nM) (Dharmacon, Lafayette, CO) using TransIT-siQuest (Mirus, Madison, WI) according to manufacturer's instructions. The transfected cells were grown for $16 \mathrm{~h}$ in complete medium, then trypsinized, diluted to the appropriate cell density, and replated in dishes for subsequent assays, including western blotting, thymidine incorporation into DNA as a parameter for cell proliferation, and propidium iodide staining for apoptosis measurement.

Legend for Supplementary figure 1. Effect of targeted silencing of EGFR expression on HGF-induced signalling, proliferative and survival activities in mouse oval cells. (A) EGFR knockdown efficiency determined by western blot analysis. Mouse Met ${ }^{f|f| f \mid x}$ oval cell lines were transfected with either nontargeting negative control siRNA (si NT) or EGFR targeting siRNA (si EGFR). Cells were then reseeded in $60 \mathrm{~mm}$ culture dishes for western blot analysis, serum-starved and treated with EGF $(20 \mathrm{ng} / \mathrm{ml})$ for $10 \mathrm{~min}$. Whole cell lysates were immunoblotted with the indicated antibodies. $\beta$-actin was used for normalization. (B) HGF-induced signalling in EGFR knockdown Met ${ }^{f \mathrm{fl} / \mathrm{fl} x}$ oval cells (si EGFR) as compared to control cells transfected with non-targeting siRNA (si NT). Cells were transfected, cultured and processed as in (A), except that they were treated with HGF $(40 \mathrm{ng} / \mathrm{ml})$ for $15 \mathrm{~min}$. (C) DNA synthesis as determined by thymidine incorporation in non-targeting siRNA-transfected (black bars) and EGFR targeting siRNA-transfected Met ${ }^{f l / f l x}$ oval cells (stripefilled bars). Cells were either left untreated (-) or treated with 20ng/ml EGF (EGF) or 40ng/ml HGF (HGF). (D) Apoptotic index in non-targeting siRNAtransfected (black bars) and EGFR targeting siRNA-transfected Met ${ }^{\text {flx/flx }}$ oval 
cells (stripe-filled bars). Cells were either left untreated (-) or treated with $1 \mathrm{ng} / \mathrm{ml}$ TGF- $\beta$ (T $\beta$ ) alone or with $40 \mathrm{ng} / \mathrm{ml}$ HGF (HGF+T $\beta)$. In $\mathrm{C}$ and $\mathrm{D}$, data are mean \pm SEM of two independent experiments run in quadruplicates. ${ }^{* *} P<0.001$ (both NT and EGFR siRNAs data sets). 


\section{Supplementary Figure}

A

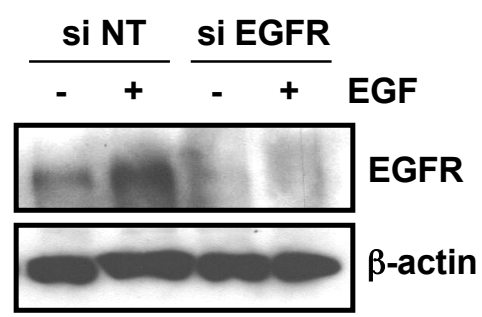

B

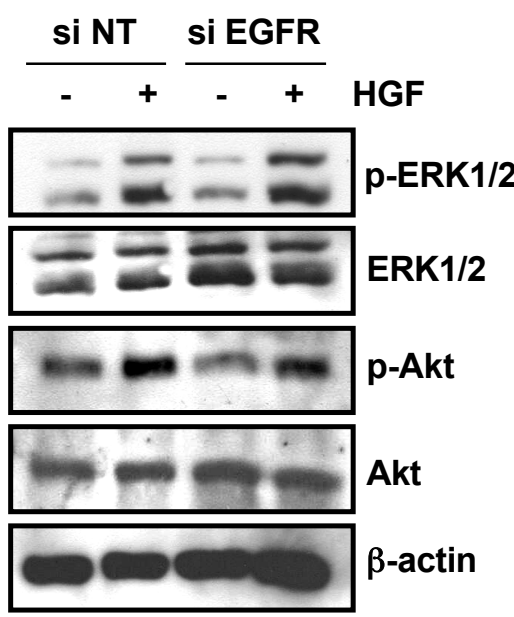

C

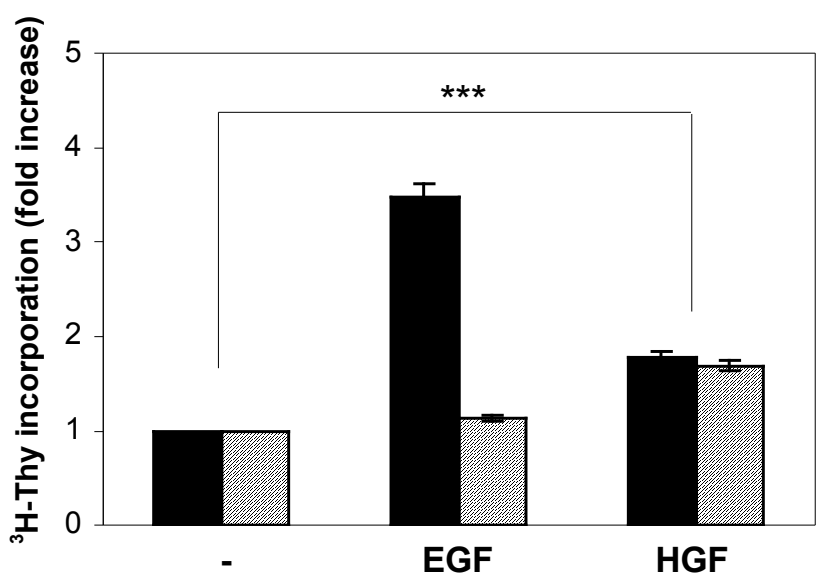

D

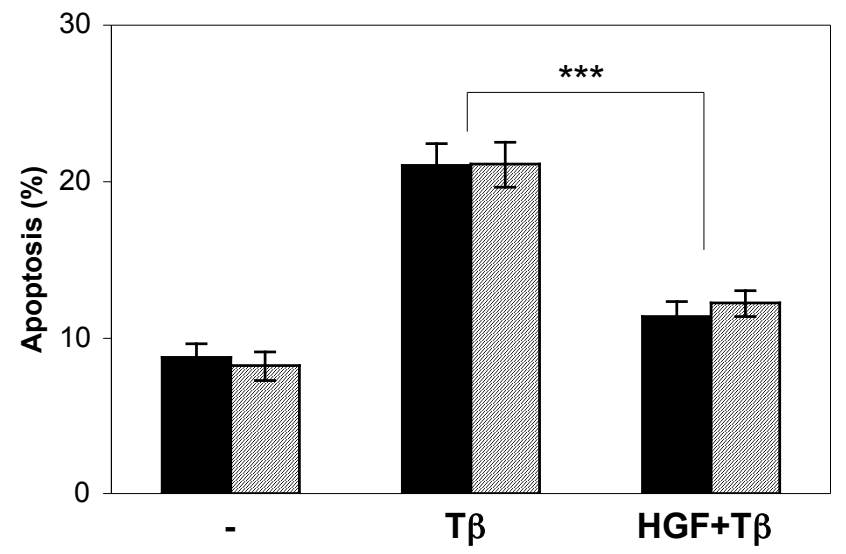

